\title{
Phenology, bunch morphology and must quality of five grapevine hybrids grafted onto two rootstocks
}

\author{
Juliana Rocha Souza ${ }^{1}$ (D), Lenon Romano Modesto 2,* (D), Pedro Henrique Gatto Juliano ${ }^{3}$ (D), José Luiz \\ Hernandes ${ }^{4}$ (D), Armando Reis Tavares ${ }^{5}$ (D), Marco Antônio Tecchio ${ }^{6}$ (D), Mara Fernandes Moura ${ }^{1,4}$ (D) \\ 1. Instituto Agronômico - Programa de Pós-Graduação em Agricultura Tropical e Subtropical - Campinas (SP), Brazil. \\ 2. Universidade Federal de Santa Catarina - Núcleo de Estudos da Uva e do Vinho -Florianópolis (SC), Brazil. \\ 3. Universidade Estadual Paulista “Júlio de Mesquita Filho" - Faculdade de Ciências Agronômicas - Departamento de Ciência do Solo - \\ Botucatu (SP), Brazil. \\ 4. Instituto Agronômico - Centro de Frutas - Jundiaí (SP), Brazil. \\ 5. Instituto de Botânica - Núcleo de Plantas Ornamentais - São Paulo (SP), Brazil. \\ 6. Universidade Estadual Paulista “Júlio de Mesquita Filho" - Faculdade de Ciências Agronômicas - Departamento de Horticultura- Jaboticabal \\ (SP), Brazil. \\ Received: May 27, 2021 | Accepted: Sep. 13, 2021 \\ Section Editor: Cláudia Sales Marinho \\ *Corresponding author: lenon modesto@hotmail.com \\ How to cite: Souza, J. R., Modesto, L. R., Juliano, P. H. G., Hernandes, J. L., Tavares, A. R., Tecchio, M. A. and Moura, M. F. (2021). \\ Phenology, bunch morphology and must quality of five grapevine hybrids grafted onto two rootstocks. Bragantia, 80 , e5621. https://doi. \\ org/10.1590/1678-4499.20210155
}

\begin{abstract}
Phenology, bunch morphology, and must quality are essential factors to the selection of grapevine cultivars for winemaking. This study aimed to evaluate five grapevine hybrids grafted onto two rootstocks, looking for fruit with the best characteristics for producing wine. The hybrids studied were 'BRS Lorena', 'IAC 21-14 Madalena', 'Moscatel de Jundiaí', 'Moscato Embrapa' and 'SR 0.501-17' grafted onto 'IAC 572 Jales' and 'IAC 766 Campinas' rootstock. Phenology was evaluated weekly, and the number of days from pruning to sprouting, flowering, and maturation was calculated. Fruit production, bunch morphology, and must quality were evaluated for each genotype and rootstock. 'SR 0.501-17' was classified as a genotype with a medium cycle, with fruit maturing 20 days earlier than the other hybrids, which were, therefore, classified as late-cycling. No interaction was noted between hybrids and rootstocks relative to bunch morphology. The must of 'Moscato Embrapa' grafted onto 'IAC 766 Campinas' rootstock had higher maturation index than that grafted onto 'IAC 572 Jales' rootstock. 'BRS Lorena' and 'SR 0.501-17' produced smaller berries, must with medium acidity, and higher soluble solid contents, as compared with other hybrids, resulting in the best bunch morphology and must quality for winemaking.
\end{abstract}

Key words: Vitis, fruits, interaction, wine.

\section{INTRODUCTION}

Crossings between the Vitis labrusca and Vitis vinifera have resulted in grapevine hybrids which have been studied worldwide, searching for materials with good adaptability to different climatic conditions, resistance to diseases, high sugar levels, and good characteristics of bunch, berry, and stalk for winemaking mostly in tropical and subtropical regions (Biasoto et al. 2014; Camargo et al. 2010; Lago Vanzela et al. 2013; Mattar et al. 2019; Vezzulli et al. 2018). Whereas Vitis labrusca is employed as part of the genetic background to develop cultivars looking for disease resistance in grapevine (Ban et al. 2016; Gąstoł 2015). Vitis vinifera has been used in grapevine breeding programs to produce genotypes with good characteristics for winemaking (Bigard et al. 2020; Wojdyło et al. 2018). 'IAC 21-14 Madalena', 'Moscatel de Jundiaí and 'SR 0.501-17', obtained by the Agronomic Institute (IAC), and 'BRS Lorena' and 'Moscato Embrapa', obtained by Embrapa, are hybrids developed for the Brazilian climate for white wine production, but more studies are needed to understand fruit morphology and quality for winemaking.

The use of rootstock is widely known to control pests and diseases in viticulture (Esmenjaud and Bouquet 2009; Zhang et al. 2009). The combination of scion and rootstock genotypes increases climatic adaptability and must quality of grapevine cultivars (Jin 
et al. 2016; Mattar et al. 2019; Zombardo et al. 2020). A variety of rootstocks are available for grapevine use, and they are adapted for different edaphoclimatic conditions (Delrot et al. 2020; Jin et al. 2016; Troncoso et al. 1999). The IAC has also developed new rootstocks, which exhibit high vegetative vigor and adaptability to acidity soil and they have shown high resistance to phylloxera and nematodes (Oliveira et al. 2020). The most used rootstocks in the subtropical region of Brazil are 'IAC 766 Campinas' and 'IAC 572 Jales' (Mattar et al. 2019). These rootstocks are resistant to phylloxera, adapted to subtropical conditions, and have specific interaction with scion, increasing fruit production and solids soluble contents (Madalon et al. 2018; Tecchio et al. 2020).

Grapevine genotypes with early or late cycle, i.e., number of days from pruning to maturation, can be adapted for better climatic conditions to grow grapes (Moura et al. 2018). Bunch morphology is an important factor used in selecting good genotypes for high must quality and disease resistance (Alonso-Villaverde et al. 2008; Melo et al. 2015). Bunch weight and size also affect grapevine production; in addition, berry weight and size, as well as stalk weight, are directly correlated with fruit yield (Molitor et al. 2011). Bunch morphology influences the concentration of sugar and phenolic compounds in the must because small and medium berries concentrated more compounds and sugar than the large berries (Melo et al. 2015). While sugar concentration is also positively correlated with maturation index, it is negatively correlated with must acidity (Gąstoł 2015). These chemical attributes are important for winemakers since they change must fermentation and, consequently, alcohol and acidity levels in wine (Gąstoł 2015; Nguela et al. 2019). Thus, this study aimed to evaluate the effects of the rootstocks 'IAC 766 Campinas' and 'IAC 572 Jales' on phenology, bunch morphology, and must quality of five white wine grapes.

\section{MATERIAL AND METHODS}

\section{Experimental conditions and plant material}

The experiment was conducted during 2015 and 2016 in Jundiaí, state of São Paulo, Brazil (2317”S 46 9"W, 715 m a.s.l.), a location with an annual rainfall of 1,400 and $1,402 \mathrm{~mm}$ and temperature of 19.5 and $21.6^{\circ} \mathrm{C}$ in 2015 and 2016, respectively. Soil was classified as red cambisol dystrophic (Embrapa 2006). Rootstocks were planted in September 2013, and the hybrids were grafted in July 2014. The grapevines were trained on a bilateral cordon using a trellis system with $2.0 \times 0.9 \mathrm{~m}$ of spacing between lines and plants, respectively. The yield pruning was performed on July 31, 2015 and August 1, 2016. The grapevines were spur pruned (two buds per spur); afterwards, $5 \%$ hydrogenated cyanamide was applied to induce and standardize sprouting. Control against fungal diseases, canopy management (sprouts, defoliation, and topping), and fertilization was carried out according to technical recommendations for the subtropical region.

Treatments consisted of combining 'BRS Lorena' ('Malvasia Bianca' × 'Seyval'), 'IAC 21-14 Madalena' ('Seibel 11342' × 'Moscatel Canelli'), 'Moscatel de Jundiaî' ('Seyve Villard 5276' × 'Pirovano 4'), 'Moscato Embrapa' ('Courderc 13' × 'July Muscat') and 'SR 0.501-17' ('Syrah' $\times$ 'Seibel 7053') grapevine hybrids, with 'IAC 572 Jales' (Vitis caribaea $\times$ '101-14 Mgt') and 'IAC 766 Campinas' ('Riparia do Traviú' $\times$ Vitis caribaea) rootstocks. The experimental design utilized randomized blocks design with a $5 \times 2$ (hybrids $\times$ rootstocks) factorial scheme with five replications during two crop seasons (2015 and 2016). The experimental plot was composed of five plants per block ( $n=25$ plants).

\section{Phenology, fruit production and bunch morphology}

Grapevine phenology was evaluated weekly from grapevine pruning to grape maturation according to Eichhorn and Lorenz (1984). Subsequently, number of days from pruning to sprouting (wooly bud \pm green showing, EL3), flowering (= flowering, 50\% caps off, EL23), and fruit maturity (berries harvest-ripe, EL38) were calculated.

The curve of grape maturation was done weekly after veraison, using a random sample of 30 berries per plot ( $n=150$ berries in five blocks per genotype/rootstock). The harvests were conducted per genotype/rootstock after laboratory procedures for determining soluble solids (SSC, ${ }^{\circ} \mathrm{Bx}>18$ ), titratable acidity (TA, percentage of tartaric acid), and juice $\mathrm{pH}$ $(\mathrm{pH} \leq 3.5)$. Soluble solids content (SSC) was determined in grape juice by direct refractometry using a digital refractometer (Reichert, model r2i300, USA), TA was determined by titration of $0.1 \mathrm{~N} \mathrm{NaOH}$ reach the equivalence point of 8.2 and $\mathrm{pH}$ 
by the direct reading of the must in potentiometer (Tecnal, model r2i300) (Instituto Adolfo Lutz 2005). Plant productivity was estimated by fruit production per grapevine (plant), and it was expressed in tons per hectares. Bunch morphology was evaluated using 50 bunches per genotype/rootstock.

\section{Must composition}

The chemical composition of must was determined after manual maceration of berries ( $\mathrm{n}=500$ berries per block). Soluble solids content was determined in grape juice by direct refractometry using a digital refractometer (Reichert, model r2i300, USA), TA was determined by titration of $0.1 \mathrm{~N} \mathrm{NaOH}$ reach the equivalence point of 8.2 and $\mathrm{pH}$ by the direct reading of the must in potentiometer (Tecnal, model r2i300) (Instituto Adolfo Lutz 2005). Fruit maturity index was calculated by the ratio between SSCs and acidity in must.

\section{Statistical analysis}

Phenology data were displayed using descriptive statistics by the lack of normal distribution. Fruit production, bunch morphology and must quality data were analyzed by variance analysis $(p>0.001)$ and Tukey's test. When the interaction between hybrids and rootstock was no significant in variance analysis, the factors were analyzed separately using Tukey's test. Principal components analysis (PCA) used all variables to characterize the different combinations between hybrids and rootstocks. Tukey's test was performed in SISVAR (Ferreira 2011) and PCA was performed using package factoextra package in R, v. 3.4.5 (R Core Team 2017).

\section{RESULTS}

\section{Phenology}

There is no interaction between hybrids and rootstock for the variable number of days from pruning to sprouting, flowering and fruit maturation. The hybrids 'BRS Lorena,' 'Moscato Jundiai' and 'SR 0501-17' were the earliest to spout (approximately 15 days after pruning [DAP]) whereas 'IAC 21-14 Madalena' was the latest hybrid to sprout at 17 ('IAC 572 Jales') and 16.3 ('IAC 766 Campinas') DAP (Table 1). 'Moscato Embrapa' was the latest hybrid to produce flowers with 57.3 ('IAC 572 Jales') and 55.5 ('IAC 766 Campinas') DAP. 'SR 0501-17' was the earliest hybrid to be harvested at 143 DAP (both rootstocks) while the latest hybrid to be harvested was 'BRS Lorena' (163 DAP for both rootstocks).

Table 1. Number of days from pruning to sprouting, flowering and fruit maturation for 'BRS Lorena', 'IAC 21-14 Madalena', 'Moscatel de Jundiaí', 'Moscato Embrapa' and 'SR 0501-17' grapevine hybrids grafted onto 'IAC 572 Jales' and 'IAC 766 Campinas' rootstocks.

\begin{tabular}{|c|c|c|c|c|}
\hline Hybrids & Rootstock & Spouting (days) & Flowering (days) & Maturation (days) \\
\hline \multirow{2}{*}{ 'BRS Lorena' } & 'IAC 572 Jales’ & 15.4 & 53.6 & 163.0 \\
\hline & 'IAC 766 Campinas' & 15.4 & 53.4 & 163.0 \\
\hline \multirow{2}{*}{ 'IAC 21-14 Madalena' } & ‘IAC 572 Jales’ & 17.0 & 53.1 & 150.0 \\
\hline & 'IAC 766 Campinas' & 16.3 & 52.8 & 150.0 \\
\hline \multirow{2}{*}{ ‘Moscatel de Jundiaí' } & 'IAC 572 Jales' & 14.7 & 51.8 & 160.5 \\
\hline & 'IAC 766 Campinas' & 15.2 & 51.4 & 160.5 \\
\hline \multirow{2}{*}{ 'Moscato Embrapa' } & 'IAC 572 Jales' & 15.6 & 57.3 & 160.5 \\
\hline & 'IAC 766 Campinas' & 15.7 & 55.5 & 160.5 \\
\hline \multirow{2}{*}{ 'SR 0501-17’ } & 'IAC 572 Jales’ & 14.6 & 51.4 & 143.5 \\
\hline & 'IAC 766 Campinas’ & 15.0 & 51.8 & 143.5 \\
\hline
\end{tabular}




\section{Fruit production, bunch morphology and must quality}

There is no interaction between hybrids and rootstock to fruit production, bunch morphology and SSC. The hybrids produced 3.05 tons of grapes per hectare with no difference among treatments. 'Moscato Embrapa' had heavier $(278.9 \mathrm{~g})$ and larger $(17.5 \mathrm{~cm}$ length and $7.6 \mathrm{~cm}$ width) bunches compared to other hybrids (Table 2). 'IAC 21-14 Madalena' produced the smallest bunch with $175.6 \mathrm{~g}$. 'Moscatel Jundiai' produced the heaviest and largest berries (2.9 g and $1.6 \mathrm{~cm}$, respectively). 'Moscatel de Jundiaí,' 'Moscato Embrapa' and 'IAC 21-14 Madalena' produced bunches with smaller stalk than 'BRS Lorena' and 'SR 0501-17'. There was no effect of rootstocks on bunch morphology. 'BRS Lorena' and 'SR 0501-17' produced the highest SSCs of grape must with 17.8 and $17.0^{\circ} \mathrm{Bx}$, respectively (Table 2). Rootstocks did not affect the must SSCs.

Table 2. Production, bunch weight, length and width, berry weight, length and width, stalk weight, and soluble solids content of grape must for five grapevine hybrids and two rootstocks.

\begin{tabular}{|c|c|c|c|c|c|c|c|c|c|}
\hline \multirow[b]{2}{*}{ Hybrids } & \multirow{2}{*}{$\begin{array}{l}\text { Production } \\
\text { kg }^{\text {plant }}{ }^{-1}\end{array}$} & \multicolumn{3}{|c|}{ Bunch } & \multicolumn{3}{|c|}{ Berry } & \multirow{2}{*}{$\begin{array}{c}\text { Stalk } \\
\text { Weight } \\
\text { (g) }\end{array}$} & \multirow{2}{*}{$\begin{array}{c}\text { Soluble } \\
\text { solids } \\
\left.\text { ( }{ }^{\circ} \mathrm{Bx}\right)\end{array}$} \\
\hline & & $\begin{array}{l}\text { Weight } \\
\text { (g) }\end{array}$ & $\begin{array}{l}\text { Length } \\
(\mathrm{cm})\end{array}$ & $\begin{array}{l}\text { Width } \\
\text { (cm) }\end{array}$ & $\begin{array}{l}\text { Weight } \\
\text { (g) }\end{array}$ & $\begin{array}{l}\text { Length } \\
(\mathrm{cm})\end{array}$ & $\begin{array}{l}\text { Width } \\
\text { (cm) }\end{array}$ & & \\
\hline 'BRS Lorena' & $2.82 a$ & $228.9 b$ & $14.5 c$ & $6.0 \mathrm{bc}$ & $2.3 c$ & $1.6 \mathrm{~b}$ & $1.50 \mathrm{bc}$ & $9.6 a$ & $17.8 a$ \\
\hline $\begin{array}{l}\text { 'IAC 21-14 } \\
\text { Madalena' }\end{array}$ & $2.94 a$ & $175.6 c$ & $13.7 c$ & $5.6 c$ & $2.4 b c$ & $1.6 \mathrm{~b}$ & $1.48 c$ & $5.7 b$ & $14.1 \mathrm{c}$ \\
\hline $\begin{array}{l}\text { 'Moscatel de } \\
\text { Jundiaí' }\end{array}$ & $3.08 a$ & $208.6 b$ & $15.1 b$ & $5.9 b c$ & $2.9 a$ & $1.8 a$ & $1.63 a$ & $8.3 a$ & $14.8 \mathrm{bc}$ \\
\hline $\begin{array}{l}\text { 'Moscato } \\
\text { Embrapa' }\end{array}$ & $3.30 a$ & $278.9 a$ & $17.5 a$ & $7.6 a$ & $2.6 a b$ & $1.8 a$ & $1.55 b$ & $6.4 b$ & $15.7 b$ \\
\hline ‘SR 0501-17’ & $3.09 a$ & $231.6 b$ & $15.7 b$ & $6.4 b$ & $2.3 c$ & $1.6 b$ & $1.48 c$ & $9.6 a$ & $17.0 \mathrm{a}$ \\
\hline \multicolumn{10}{|l|}{ Rootstock } \\
\hline 'IAC 572 Jales’ & 3.09 & 225.3 & 15.3 & 6.4 & 2.6 & 1.7 & 1.5 & 8.0 & 15.96 \\
\hline $\begin{array}{l}\text { 'IAC } 766 \\
\text { Campinas' }\end{array}$ & 3.00 & 224.2 & 15.5 & 6.2 & 2.5 & 1.7 & 1.5 & 7.8 & 15.85 \\
\hline
\end{tabular}

Note. Means with different letters present a significant difference in the Tukey's test at $5 \%$ probability.

The hybrids showed interaction with rootstock to must acidity and maturation index (Table 3). IAC 766 resulted the lowest acidity to 'Moscato Embrapa' (0.48 g of tartaric acid) in must than to other genotypes. 'Moscato Embrapa' grafted onto 'IAC 766 Campinas' showed higher fruit maturation index (33.40) than grafted onto 'IAC 572 Jales' (Table 3). 'Moscatel de Jundiai' on both rootstocks showed the lowest fruit maturation index compared to the other grapevine hybrids.

Table 3. Titratable acidity (TA) of grape must and maturation index of five grape hybrids grafted onto two rootstocks.

\begin{tabular}{|c|c|c|c|}
\hline Hybrids & Rootstock & TA (g tartaric acid) & Maturation index (SSC/TA) \\
\hline \multirow{2}{*}{ 'BRS Lorena' } & 'IAC 572 Jales’ & $0.80 a b$ & $23.04 b c$ \\
\hline & 'IAC 766 Campinas' & $0.80 \mathrm{ab}$ & $22.50 \mathrm{bc}$ \\
\hline \multirow{2}{*}{ 'IAC 21-14 Madalena' } & 'IAC 572 Jales’ & $0.76 \mathrm{~b}$ & $18.70 \mathrm{~cd}$ \\
\hline & 'IAC 766 Campinas’ & $0.74 b c$ & $19.71 \mathrm{~cd}$ \\
\hline \multirow{2}{*}{ 'Moscatel de Jundiaí' } & 'IAC 572 Jales’ & $0.92 a$ & $16.79 d$ \\
\hline & 'IAC 766 Campinas' & $0.92 a$ & $16.59 d$ \\
\hline \multirow{2}{*}{ 'Moscato Embrapa' } & 'IAC 572 Jales’ & $0.60 \mathrm{~cd}$ & $26.23 b$ \\
\hline & 'IAC 766 Campinas' & $0.48 d$ & $33.40 a$ \\
\hline \multirow{2}{*}{ ‘SR 0501-17’ } & 'IAC 572 Jales’ & $0.74 \mathrm{bc}$ & $23.69 b c$ \\
\hline & 'IAC 766 Campinas' & $0.71 b c$ & $23.68 b c$ \\
\hline
\end{tabular}

Note. Means with different letters presented a significant difference in Tukey's test at $5 \%$ probability. SSC = soluble solids contents. 


\section{Principal components analysis}

The two first principal components explained $67.3 \%$ of the experimental variance (Fig. 1). Performance of the hybrids showed no difference between rootstocks. The combinations of each hybrid with different rootstocks were grouped. The first principal component (39.2\%) characterized the hybrids using the number of days from pruning to flowering, must acidity, fruit maturation index, and bunch size and weight. 'Moscato Embrapa' produced the biggest and heaviest bunch with the lowest must acidity, highest number of days to flowering and fruit maturation index. 'IAC 21-14 Madalena' produced the smallest and lightest bunch with the highest must acidity, lowest fruit maturation index, and number of days to flowering. 'BRS Lorena', 'Moscatel de Jundiaí' and 'SR 0501-17' produced medium-sized bunches with intermediate values for number of days to flowering, must acidity and fruit maturation index.

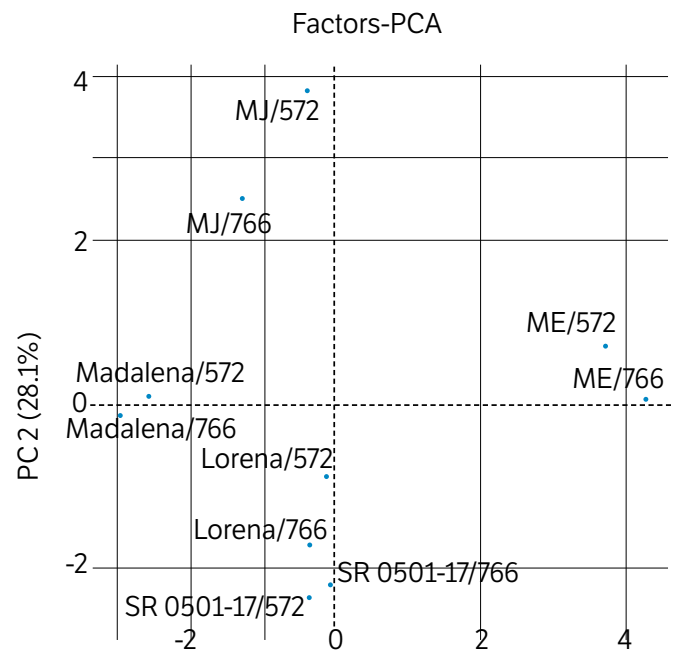

PC 1 (39.2\%)

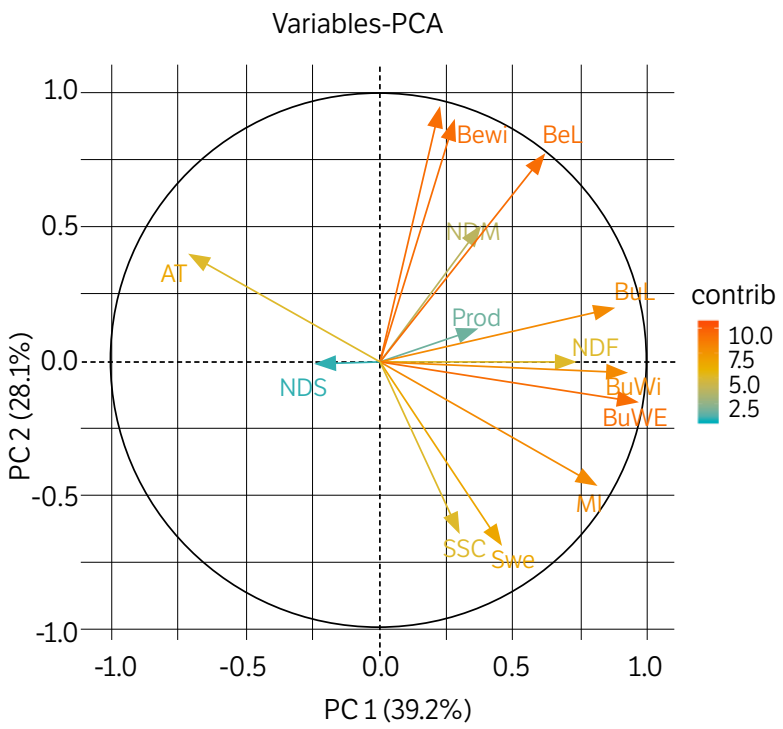

Figure 1. Principal component analysis for the interaction between five grapevine hybrids grafted onto two rootstocks using the number of days from punning to sprouting (NDS), flowering (NDF) and maturation (NDM); production; bunch weight (BuWe), length (BuL), and width (BuWi); berry weight (BeWe), length (BeL) and width (BeWi); stalk weight (SWe); soluble solids content (SSC); titratable acidity (TA) and maturation index (MI).

Note. 'BRS Lorena' (LORENA), 'IAC 21-14 Madalena' (MADALENA), 'Moscatel de Jundiaí (MJ), 'Moscato Embrapa' (ME) and 'SR 0.501-17’(SR 0.501-17), and two rootstock, 'IAC 572 Jales' (572) and 'IAC 766 Campinas' (766).

The second principal component (28.1\%) used stalk weight, SSCs, berry weight, and berry size to characterize the hybrids (Fig. 1). 'BRS Lorena' and 'SR 0501-17' produced the lightest and smallest berries with the highest SSCs in must. 'Moscatel de Jundiai' produced the biggest and heaviest berries with the lowest SSCs in must. 'IAC 21-14 Madalena' and 'Moscato Embrapa' produced medium-size berries and intermediate SSCs in must.

\section{DISCUSSION}

The number of days from pruning to grapevine sprouting are positively correlated with number of days from pruning to grapevine flowering (Moura et al. 2018). In this study was observed a small difference in the number of days from pruning to sprouting and from pruning to flowering between the hybrids compared to the number of days to complete maturation. 'SR 0501-17' and 'IAC 21-14 Madalena' showed a median cycle which ranged from 134 to 156 days from pruning to harvest, respectively (Moura et al. 2018). 'BRS Lorena', 'Moscato Embrapa', and 'Moscatel de Jundiaí showed late-cycling ranged from 156 to 174 days from pruning to harvest (Moura et al. 2008). The rootstocks did not affect the phenology of the studied grapevines. Corroborating the results, 'IAC 572 Jales' and 'IAC 766 Campinas' rootstocks, similar to 'IAC 113 Tropical' and 
'IAC 571-6 Jundiaí' rootstocks, did not influence the phenology of 'SR 501-17' grapevine (Mattar et al. 2019). However, several studies have reported that rootstock change the phenology of Vitis vinifera cultivars, such as Albarín Negro, Verdejo Negro, and Cabernet Sauvignon due to climate and soil adaptation in different regions (Loureiro et al. 2016; Loureiro et al. 2020; Miele 2019).

Bunch morphology, such as total number of berries and bunch length, is an important characteristic for fruit quality and disease control (Alonso-Villaverde et al. 2008; Tello and Ibáñez 2014) as presented in Cabernet Franc, Cabernet Sauvignon, Sauvignon Blanc and Riesling (Tello et al. 2015). In this study, 'Moscato Embrapa' produced the heaviest bunch with bigger size bunches; additionally, 'Moscatel de Jundiai' with the heaviest berries produced bigger berries. Compacted bunches have a higher susceptibility to pathogenic infections, such as Botrytis cinerea (Vail and Marois 1991) and Colletotrichum spp. (Echeverrigaray et al. 2020). 'BRS Lorena' and 'SR 501-17' produced heavy stalk bunches with light berries, resulting in bunches with low compactness. The space between berries facilitates pathogen control, in turn improving microclimatic conditions because of better sun and wind exposure (Molitor et al. 2011; Würz et al. 2020). Bigger bunches with small berries have more space between berries (Tello et al. 2015), resulting in lower humidity and, consequently, less favorable conditions for pathogens to develop (Alonso-Villaverde et al. 2008). Berry mass, volume, and skin area are positively correlated with the berry size of cultivar Syrah (Melo et al. 2015). Bunch morphology of all studied hybrids was not influenced by rootstocks. Bunch morphology of the cultivar Albariño was not modified when grafted on '191-7', '101-14 MG', and '3309 C' (Loureiro et al. 2020). Also, 'IAC 766 Campinas,' 'IAC 572 Jales,' 'IAC 131', and 'IAC 571-2' rootstocks did not influence bunch morphology of the white grape hybrid 'SR 501-17' (Mattar et al. 2019). However, different scion/ rootstock combinations may require specific irrigation, pruning, or canopy management to optimize fruit and, potentially, wine composition (Clingeleffer et al. 2019).

The interaction between cultivar and rootstock affects must quality, altering volatile acidity concentration and fruit maturation index (Loureiro et al. 2016). In this study, 'Moscato Embrapa' grafted onto 'IAC 766 Campinas' rootstock showed a higher fruit maturation index than that grafted onto 'IAC 572 Jales' rootstock. Rootstock affects genotype performance, varying carbohydrate contents in roots, trunks, and shoots (Köse et al. 2014). Good scion-rootstock interaction can increase SSCs and decrease total acidity in must, resulting in better quality wines (Loureiro et al. 2016). The variety Albariño grafted onto '41B' rootstock tend to accumulate more sugars in grapes; consequently, the resulting wines have a higher volume of ethanol (Vilanova et al. 2021). Selecting the correct rootstock for wine grape vineyards is very important since rootstocks are used to overcome specific soil limitations, such as soil $\mathrm{pH}$, or biological factors, such as phylloxera, nematodes, and cotton root rot. 'IAC 766 Campinas' and 'IAC 572 Jales' rootstocks performed equally and can be recommended to graft the hybrids 'BRS Lorena,' 'IAC 21-14 Madalena,' 'Moscatel de Jundiaí, 'Moscato Embrapa' and 'SR 0.501-17' in the state of São Paulo, Brazil. 'IAC 766 Campinas' rootstock is less vigorous than 'IAC 572 Jales' and not indicated for planting in regions with high temperatures, such as northwestern São Paulo (Camargo et al 2010). 'IAC 572 Jales' is a very vigorous rootstock, and it is adapted to the environmental conditions southeast and northwest of São Paulo and to acidic soils and soil nematodes (Pommer et al. 1997).

However, the rootstocks did not influence must from the other hybrids studied. The rootstock effect is more significant in terms of phenolic compounds on must since grapes from grapevines grafted onto 'IAC 572 Jales' showed higher concentrations of tartaric and malic acids, while those grafted onto '1103P' presented high levels of total phenols and nonflavonoids (Oliveira et al. 2020). Hybrids with the highest bunch size showed a higher fruit maturation index because of low acidity in the must. In addition, hybrids with the smallest berries and the biggest stalk produced the highest SSCs. High maturation index indicated more SSC on the must than acidity, resulting in better proportion to make wine because the high acidity affects the growth of the microorganism and low sugar decreases the alcohol volume (Bayo-Canha et al. 2019). The hybrid 'Moscatel de Jundiai' showed lower maturation index than the other hybrids, average at 16.5. The white hybrids 'IAC Rainha,' 'IAC Madalena' and 'BRS Lorena' showed maturation index ranged from 20.9 to 27.1 (Tecchio et al. 2020), values observed to 'BRS Lorena' and 'SR 501-17囚 in this study, average value at 22.8 and 24.1, respectively. However, 'Moscato Embrapa' showed average maturation index at 29.9. Considering physical, chemical, and sensory characteristics, small- and medium-sized berries are more suitable for winemaking than large-sized berries (Melo et al. 2015; Tello and Ibáñez 2018). 


\section{CONCLUSION}

The hybrids 'BRS Lorena' and 'SR 501-17' showed medium bunches with small berries, high SSCs and must with medium acidity, resulting in better characteristics for white winemaking than 'IAC 21-14 Madalena,' 'Moscato Embrapa' and 'Moscatel de Jundiaí. 'BRS Lorena' and 'SR 501-17' showed a difference in the number of days from pruning to maturation. Only maturation index of Moscato Embrapa grape was affected by rootstock.

\section{AUTHORS' CONTRIBUTION}

Conceptualization: Moura M. F., Hernandes J. L. and Tecchio M. A.; Formal Analyses: Modesto L. R., Moura M. F. and Tavares A. R.; Investigation: Moura M. F., Souza J. R., Hernandes J. L., Juliano P. H. G. and Modesto L. R.; Writing Original Draft: Moura M. F., Tavares A. R. and Modesto L. R.; Writing - Review and Editing: Moura M. F., Tavares A. R. and Modesto L. R. Coordination: Moura M. F.; Funding Acquisition: Moura M. F.

\section{DATA AVAILABILITY STATEMENT}

Not applicable.

\section{FUNDING}

Coordenação de Aperfeiçoamento de Pessoal de Nível Superior

[https://doi.org/10.13039/501100002322]

Finance Code 001

Fundação de Amparo à Pesquisa do Estado de São Paulo

[https://doi.org/10.13039/501100001807]

Grant No. 2012/00292-9

\section{REFERENCES}

Alonso-Villaverde, V., Boso, S., Santiago, J. L., Gago, P. and Martínez, M.-C. (2008). Relationship between susceptibility to Botrytis bunch rot and grape cluster morphology in the Vitis vinifera L. cultivar Albariño. International Journal of Fruit Science, 8, 251-265. https://doi. org/10.1080/15538360802597481

Ban, Y., Mitani, N., Sato, A., Kono, A. and Hayashi, T. (2016). Genetic dissection of quantitative trait loci for berry traits in interspecific hybrid grape (Vitis labruscana $\times$ Vitis vinifera). Euphytica, 211, 295-310. https://doi.org/10.1007/s10681-016-1737-8

Bayo-Canha, A., Costantini, L., Fernández-Fernández, J. I., Martínez-Cutillas, A. and Ruiz-García, L. (2019). QTLs related to berry acidity identified in a wine grapevine population grown in warm weather. Plant Molecular Biology Reporter, 37, 157-169. https://doi.org/10.1007/ s11105-019-01145-6

Biasoto, A. C. T., Netto, F. M., Marques, E. J. N. and Silva, M. A. A. P. (2014). Acceptability and preference drivers of red wines produced from Vitis labrusca and hybrid grapes. Food Research International, 62, 456-466. https://doi.org/10.1016/j.foodres.2014.03.052 
Bigard, A., Romieu, C., Sire, Y. and Torregrosa, L. (2020). Vitis vinifera L. diversity for cations and acidity is suitable for breeding fruits coping with climate warming. Frontiers in Plant Science, 11, 01175. https://doi.org/10.3389/fpls.2020.01175

Camargo, U. A., Maia, J. D. G. and Ritschel, P. (2010). Embrapa Uva e Vinho: Novas cultivares brasileiras de uva. Bento Gonçalves: Embrapa Uva e Vinho.

Clingeleffer, P., Morales, N., Davis, H. and Smith, H. (2019). The significance of scion $\times$ rootstock interactions. OENO One, 53, $335-346$. https://doi.org/10.20870/oeno-one.2019.53.2.2438

Delrot, S., Grimplet, J., Carbonell-Bejerano, P., Schwandner, A., Bert, P.-F., Bavaresco, L., Costa, L. D., Di Gaspero, G., Duchêne, E., Hausmann, L., Malnoy, M., Morgante, M., Ollat, N. and Vezzulli, S. (2020). Genetic and genomic approaches for adaptation of grapevine to climate change. In C. Kole (Ed.), Genomic designing of climate-smart fruit crops (p. 157-270). Cham: Springer. https://doi. org/10.1007/978-3-319-97946-5_7

Echeverrigaray, S., Scariot, F. J., Fontanella, G., Favaron, F., Sella, L., Santos, M. C., Schwambach, J., Pedrotti, C. and Delamare, A. P. L. (2020). Colletotrichum species causing grape ripe rot disease in Vitis labrusca and $V$. vinifera varieties in the highlands of southern Brazil. Plant Pathology, 69, 1504-1512. https://doi.org/10.1111/ppa.13240

Eichhorn, K. W. and Lorenz, D. H. (1984). Phaenologische entwicklungsstadien der rebe. The European and Mediterranean Plant Protection Organization, 14, 295-298.

[Embrapa] Empressa Brasileira de Pesquisa Agropecuária. (2006). Sistema brasileiro de classificação de solos. Rio de Janeiro: Embrapa Solos.

Esmenjaud, D. and Bouquet, A. (2009). Selection and application of resistant germplasm for grapevine nematodes management. In A. Ciancio and K. G. Mukerji (Eds.), Integrated management of fruit crops nematodes (p. 195-214). Dordrecht: Springer. https://doi. org/10.1007/978-1-4020-9858-1_8

Ferreira, D. F. (2011). Sisvar: A computer statistical analysis system. Ciência e Agrotecnologia, 35, 1039-1042. https://doi.org/10.1590/ S1413-70542011000600001

Gąstoł, M. (2015). Vineyard performance and fruit quality of some interspecific grapevine cultivars in cool climate conditions. Folia Horticulturae, 27, 21-31. https://doi.org/10.1515/fhort-2015-0011

Instituto Adolfo Lutz. (2005). Métodos físico-químicos para análise de alimentos. São Paulo: Instituto Adolfo Lutz.

Jin, Z., Sun, H., Sun, T., Wang, Q. and Yao, Y. (2016). Modifications of ‘Gold Finger’ grape berry quality as affected by the different rootstocks. Journal of Agricultural and Food Chemistry, 64, 4189-4197. https://doi.org/10.1021/acs.jafc.6b00361

Köse, B., Karabulut, B. and Ceylan, K. (2014). Effect of rootstock on grafted grapevine quality. European Journal of Horticultural Science, 79, 197-202.

Lago-Vanzela, E. S., Rebello, L. P. G., Ramos, A. M., Stringheta, P. C., Da-Silva, R., García-Romero, E., Gómez Alonso, S. and Hermosín-Gutiérrez, I. (2013). Chromatic characteristics and color-related phenolic composition of Brazilian young red wines made from the hybrid grape cultivar BRS Violeta (“BRS Rúbea” × “IAC 1398-21”). Food Research International, 54, 33-43. https://doi.org/10.1016/j.foodres.2013.06.008

Loureiro, M. D., Moreno-Sanz, P., García, A., Fernández, O., Fernández, N. and Suárez, B. (2016). Influence of rootstock on the performance of the Albarín Negro minority grapevine cultivar. Scientia Horticulturae, 201, 145-152. https://doi.org/10.1016/j.scienta.2016.01.023

Loureiro, M. D., Moreno-Sanz, P. and Suárez, B. (2020). Evaluation of rootstocks for the 'Verdejo Negro’ cultivar. Ciência e Técnica Vitivinícola, 35, 120-132. https://doi.org/10.1051/ctv/20203502120

Madalon, F. Z., Lima, V. L. S., Pratissoli, D., Meneghelli, C. M., Carvalho, J. R. and Zucoloto, M. (2018). Occurrence of grape phylloxera Daktulosphaira vitifoliae Fitch (Hemiptera: Phylloxeridae) in the state of Espirito Santo. Journal of Experimental Agriculture International, 20, 1-5. https://doi.org/10.9734/JEAl/2018/39074 
Mattar, G. S., Modesto, L. R., Hernandes, J. L., Tecchio, M. A. and Moura, M. F. (2019). Cycle, physicochemical characterization and climatic adaptation of a white hybrid grape on different rootstocks. Bragantia, 78, 470-478. https://doi.org/10.1590/1678-4499.20190010

Melo, M. S., Schultz, H. R., Volschenk, C. G. and Hunter, J. J. (2015). Berry size variation of Vitis vinifera L. cv. Syrah: Morphological dimensions, berry composition and wine quality. South African Journal of Enology and Viticulture, 36, 1-10. https://doi.org/10.21548/36-1-931

Miele, A. (2019). Rootstock-scion interaction: 6. phenology, chilling and heat requirements of cabernet sauvignon grapevine. Revista Brasileira de Fruticultura, 41, e-446. https://doi.org/10.1590/0100-29452019446

Molitor, D., Behr, M., Fischer, S., Hoffmann, L. and Evers, D. (2011). Timing of cluster-zone leaf removal and its impact on canopy morphology, cluster structure and bunch rot susceptibility of grapes. OENO One, 45, 149-159. https://doi.org/10.20870/oeno-one.2011.45.3.1495

Moura, M. F., Modesto, L. R., Dias, C. T. S., Hernandes, J. L., Saito, M. Z. and Santos, T. S. (2018). Phenotypic divergence of grapes using productive cycle. Australian Journal of Crop Science, 12, 749-754. https://doi.org/10.21475/ajcs.18.12.05.PNE880

Nguela, J. M., Vernhet, A., Julien-Ortiz, A., Sieczkowski, N. and Mouret, J.-R. (2019). Effect of grape must polyphenols on yeast metabolism during alcoholic fermentation. Food Research International, 121, 161-175. https://doi.org/10.1016/j.foodres.2019.03.038

Oliveira, J. B., Laureano, O., Castro, R., Pereira, G. E. and Ricardo-da-Silva, J. M. (2020). Rootstock and harvest season affect the chemical composition and sensory analysis of grapes and wines of the Alicante Bouschet (Vitis vinifera L.) grown in a tropical semi-arid climate in Brazil. OENO One, 54, 1021-1039. https://doi.org/10.20870/oeno-one.2020.54.4.2553

Pommer, C. V., Passos, I. R. S., Terra, M. M. and Pires, E. J. P. (1997). Variedades de videira para o estado de São Paulo. Campinas: Instituto Agronômico.

R Core Team (2017). R: A Language and environment for statistical computing. R Foundation for Statistical Computing. Vienna. Austria. http://www.r-project.org

Tecchio, M. A., Silva, M. J. R., Callili, D., Hernandes, J. L. and Moura, M. F. (2020). Yield of white and red grapes, in terms of quality, from hybrids and Vitis labrusca grafted on different rootstocks. Scientia Horticulturae, 259,108846. https://doi.org/10.1016/j.scienta.2019.108846

Tello, J. and Ibáñez, J. (2014). Evaluation of indexes for the quantitative and objective estimation of grapevine bunch compactness. Vitis, 53, 9-16. https://doi.org/10.5073/vitis.2014.53.9-16

Tello, J. and Ibáñez, J. (2018). What do we know about grapevine bunch compactness? A state of the art review. Australian Journal of Grape and Wine Research, 24, 6-23. https://doi.org/10.1111/ajgw.12310

Tello, J., Aguirrezábal, R., Hernáiz, S., Larreina, B., Montemayor, M. I., Vaquero, E. and lbáñez, J. (2015). Multicultivar and multivariate study of the natural variation for grapevine bunch compactness. Australian Journal of Grape and Wine Research, 21, $277-289$.

Troncoso, A., Matte, C., Cantos, M. and Lavee, S. (1999). Evaluation of salt tolerance of in vitro-grown grapevine rootstock varieties. Vitis, 38, 55-60. https://doi.org/10.5073/vitis.1999.38.55-60

Vail, M. E. and Marois, J. J. (1991). Grape bunch architecture and the susceptibility of berries to Botrytis cinerea. Phytopathology, 81, $188-191$. Vezzulli, S., Vecchione, A., Stefanini, M. and Zulini, L. (2018). Downy mildew resistance evaluation in 28 grapevine hybrids promising for breeding programs in Trentino region (Italy). European Journal of Plant Pathology, 150, 485-495. https://doi.org/10.1007/s10658-017-1298-2

Vilanova, M., Genisheva, Z., Tubío, M., Alvarez, K., Lissarrague, J. R. and Oliveira, J. M. (2021). Rootstock effect on volatile composition of Albariño wines. Applied Sciences, 11, 2135. https://doi.org/10.3390/app11052135

Wojdyło, A., Samoticha, J., Nowicka, P. and Chmielewska, J. (2018). Characterisation of (poly)phenolic constituents of two interspecific red hybrids of Rondo and Regent (Vitis vinifera) by LC-PDA-ESI-MS QTof. Food Chemistry, 239, 94-101. 
Würz, D. A., Rufato, L., Bogo, A., Allebrandt, R., Bem, B. P., Marcon Filho, J. L., Brighenti, A. F. and Bonin, B. F. (2020). Effects of leaf removal on grape bunch architecture and control of Botrytis bunch rot in Sauvignon Blanc grapevines in Southern Brazil. Crop Protectiom, 131, 105079. https://doi.org/10.1016/j.cropro.2020.105079

Zhang, J., Hausmann, L., Eibach, R., Welter, L. J., Töpfer, R. and Zyprian, E. M. (2009). A framework map from grapevine V3125 (Vitis vinifera 'Schiava grossa' $\times$ 'Riesling') $\times$ rootstock cultivar 'Börner' (Vitis riparia $\times$ Vitis cinerea) to localize genetic determinants of phylloxera root resistance. Theoretical and Applied Genetics, 119, 1039-1051. https://doi.org/10.1007/s00122-009-1107-1

Zombardo, A., Mica, E., Puccioni, S., Perria, R., Valentini, P., Mattii, G. B., Cattivelli, L. and Storchi, P. (2020). Berry quality of grapevine under water stress as affected by rootstock-scion interactions through gene expression regulation. Agronomy, 10, 680. https://doi. org/10.3390/agronomy10050680 